\title{
Studies Employing the Unified Theory of Acceptance And Use Of Technology (UTAUT) As a Guideline for The Research: Literature Review of the Saudi Context.
}

\author{
Abdulrahman M. Alshabeb \\ Department of English, College of Languages and Translation \\ Al Imam Mohammed Ibn Saud Islamic University, Riyadh, Saudi Arabia. \\ Omran Alharbi \\ Glasgow university \\ Glasgow, UK \\ Riam K. Almaqrn \\ Faculty of Education Majmah University \\ Majmah, Saudi Arabia \\ Haifa Abdullah Albazie \\ Al-Jouf University
}

\begin{abstract}
Theoretical framework models are widely employed by researchers because these models are able to provide an in-depth understanding of the phenomena under investigation. The models most commonly adopted by researchers in the field of e-learning are the Technology Acceptance Model (TAM) and the Unified Theory of Acceptance and Use of Technology (UTAUT). This paper presents a review of studies that have included the UTAUT framework as a guideline for the research. More specifically, this paper concentrates on research that has been conducted in Saudi Arabia. The results of this review indicate that according to the review and an analysis of previous studies, facilitating conditions, performance expectancy and effort expectancy have positive effects on users' intentions to integrate and adopt E-Learning technologies. Finally, this paper presents and highlights area for future work.
\end{abstract}

Keywords: Saudi Arabia, Literature review and UTAUT

\section{INTRODUCTION}

In recent years, many researchers have carried out their research based on the UTAUT in order to determine which factors and elements influence users' intentions to use technology strategies in their education setting. "The theory was developed through the review and integration of eight dominant theories and models, namely: the Theory of Reasoned Action (TRA), the Technology Acceptance Model (TAM), the Motivational Model, the Theory of Planned Behaviour (TPB), a 
combined TBP/TAM, the Model of PC Utilization, Innovation Diffusion Theory (IDT), and Social Cognitive Theory (SCT)" (Williams, Rana and Dwivedi, 2015, p.444). This provides an overview of studies conducted in the Saudi education environment that used and adopted this model as a guideline for the research.

This paper first offers the introduction and definition of the UTAUT and framework. After that the purpose and intention of the paper are described and the literature review presented. The methods applied for this research are mentioned, and then the findings and outcomes are discussed. Finally, the conclusion and suggestions for future research are offered.

\section{AIM AND OBJECTIVE}

The main goal of this study is to review recently published papers and articles that used the UTAUT as a guideline for research in the Saudi context, in order to identify any gaps in the literature.

\section{LITERATURE REVIEW}

This section will provide a review of recent studies conducted in Saudi universities or schools. It focuses on research that has been published recently and which used and adopted the UTAUT Model and framework to guide the research. All of the reviewed studies were either published in peerreviewed journals, or as Master's or Doctoral theses.

Several studies have used the UTAUT as a guide for research in the Saudi context. In 2017, Alharbi, Alotebi, Masmali and Alreshidi carried out research at Hail University in Saudi Arabia. The aim of their paper was to investigate the factors that influenced university teachers' intentions to use mobile learning. The research tool was a questionnaire. The questionnaire was based on the UTAUT Model. The sample consisted of 80 faculty members, male and female. The outcomes showed that effort expectancy, performance experience, facilitating conditions and social influence altogether predicted the faculty members' adoption of M-Learning, as 67 per cent of the variation was found to be caused by these variables in the multiple regression analysis. The findings also showed that effort expectancy is the best predictor of teachers' behavioural intentions to use M-Learning.

Along the same lines, recently Alshehri, Rutter and Smith (2019) conducted research at King Kalid University. The aim of the research was to determine the factors that influence learners' intentions to utilise the Learning Management System (LMS) and predict their actual practice. The sample of the research consisted of 171 participants from different colleges. The research tool was a survey based on the UTAUT Model. The primary results of this paper indicated that performance expectancy, technical support and social influence were direct contributors to an individual's behavioural intention to integrate the LMS. Other parameters, for instance effort expectancy and facilitating conditions, were not found to be substantial predictors. Technical support, however, was found to be vital in shaping the acceptance and uptake of Blackboard. On the other hand, facilitating conditions were found to have a significant influence on Blackboard uptake in the Saudi education environment.

In addition, research in Saudi Arabia was published in 2019 by Alasmari and Zhang. The study sample was 591 male and 612 female students. Fifteen participated in interviews. The main tool was an online survey founded on the UTAUT Model. The study findings indicated that the facilitating conditions were not significant in predicting learners' behavioural intention to use M-Learning. 
Alshabeb, A. M., Alharbi, O., Almaqrn, R. K., \& Albazie, H. A. (2020). Studies employing the unified theory of acceptance and use of technology (UTAUT) as a guideline for the research: Literature review of the Saudi context. Advances in Social Sciences Research Journal, 7(4) 18-23.

Furthermore, this study showed that other variables such as the characteristics of mobile learning, effort expectancy, learning expectancy and social influence were significant predictors of learners' intentions to use M-Learning technologies. In addition, the results stated that social influence was the only construct moderated by gender, as male students displayed a stronger behavioural intention to integrate M-Learning than female students.

Zalah (2018) carried out research in Jazan city in Saudi secondary schools. The sample was instructors only, with a total number of 347. The study's purpose was to examine the acceptance of E-Learning technology tools among secondary school teachers. The study used mixed methods for collecting the data. The questionnaire was constructed based on the UTAUT Model. The major results and findings of this research were that anxiety had a significant negative effect on instructors' and tutors' intention to use E-Learning technologies and methods. However, the results also revealed that other factors such as attitudes, effort expectancy, education policy and performance had positive effects on tutors' intention to integrate E-Learning techniques. Moreover, the results indicated that facilitating conditions, behavioural intentions and instructors' educational experience had positive effects on the actual usage of E-Learning strategies.

In 2017, Alasmari conducted a study that aimed to explore learners' acceptance of M-Learning technology. The sample consisted of students (1203). The study tools were a questionnaire based on the UTAUT Model and interviews with 15 students. The findings revealed that mobile learning characteristics, social influence, learning expectancy, social influence and effort expectancy were predictors of leaners' intentions to usage M-Learning technology. Furthermore, the results stated that the social influence construct was the only construct moderated by gender as males presented a stronger behavioural intention to integrate M-Learning than females. The outcomes also indicated that E-Learning experience, age and gender had a moderating effect on the behavioural intention to use M-Learning. However, other factors such as self-management and facilitating conditions of learning were found to be significant predictors of learners' behavioural intention and usage behaviour with regard to M-Learning technology.

Along similar lines, Al Marwani conducted a study in 2016. The main goal of the research was to determine the factors that influenced learners' and teachers' intention to use M-Learning in their education environment. The researcher used a questionnaire based on the UTAUT framework as a guideline for the research and data were collected from 878 students and 65 teachers at Taibah University in Saudi Arabia. In general, the study results revealed that the social influence variable, hedonic, facilitating conditions, performance expectancy, habit and motivation accounted for $49.3 \%$ of the variance in the behavioural intention to adopt M-Learning technologies in learning English as a foreign language.

Moreover, Khan (2017) carried out research in the Eastern Province of Saudi Arabia. The study attempted to scrutinise the factors such as the hedonic motivation, facilitating conditions, effort expectancy, habit, performance expectancy and social influence of tutors' behavioural intentions to adopt the LMS in the Saudi academic environment, by adopting the UTAUT Model. The researcher constructed a questionnaire based on the UTAUT framework. The sample was only 316 faculty members. Also, the research employed a focus group interview in order to obtain more data about the study phenomenon. The study results show that facilitating conditions were the strongest predictor of behavioural intention to accept an LMS, followed by performance expectancy and 
hedonic motivation. Moreover, social influence and effort expectancy had a positive impact on behavioural intention. As well as these findings, the research indicated that there was significant relationship between behavioural intention and use behaviour.

\section{METHODOLOGY}

This study explored the UTAUT research carried out in the Saudi context. The literature search was conducted in many relevant websites such as Google Scholar, university libraries, conference procedures and on line databases. Key words such as UTAUT and the Unified Theory of Acceptance and Use of Technology were used to obtain results from article abstracts or titles. Each article selected was charted in order to provide a summary of each study and its theme. This allowed the identification of gaps in the literature. These charts provide the final results for this paper. In terms of ethics, as this study only reviewed the literature about the UTAUT framework and model and there were no study participants, there was no need to obtain ethical approval for conducting this paper.

\section{RESULTS}

This section presents the essential findings from the review and analysis of the previous studies. It also makes a brief comparison of the results from these studies.

The results from Alharbi, Alotebi, Masmali and Alreshidi (2017) indicated that effort expectancy is the best predictor of teachers' behavioural intentions to use M-Learning. This result is in disagreement with Alshehri, Rutter and Smith (2019) who reported that effort expectancy and facilitating conditions were not substantial predictors. Alasmari and Zhang (2019) found that certain characteristics of M-Learning such as effort expectancy, learning expectancy and social influence were significant predictors of learners' intentions to use M-Learning technologies. However, in a study conducted by Zalah (2018), facilitating conditions, behavioural intentions and instructors' educational experience had positive effects on the actual usage of E-Learning strategies. On the other hand, Alasmari (2017) reported that other factors such as self-management and facilitating conditions of learning were found to be significant constructs in predicting learners' behavioural intention and usage behaviour related to M-Learning technology. These results were in partial agreement with the outcomes of the study conducted by Khan (2017). Khan's research findings show that facilitating conditions were the strongest predictor of behavioural intention to accept an LMS, followed by performance expectancy and hedonic motivation. Finally, Al Marwani's (2016) study results showed that social influence, hedonic, facilitating conditions, performance expectancy, habit and motivation accounted for $49.3 \%$ of the variance in the behavioural intention to adopt M-Learning technologies. These findings were in agreement with some of the results from the studies by Khan (2017), Alshehri (2019) and Alharbi et al. (2017). Table 1 summarises the reviewed studies in terms of author name and year, sample and results. 
Alshabeb, A. M., Alharbi, O., Almaqrn, R. K., \& Albazie, H. A. (2020). Studies employing the unified theory of acceptance and use of technology (UTAUT) as a guideline for the research: Literature review of the Saudi context. Advances in Social Sciences Research Journal, 7(4) 18-23.

Table 1: Summary of the studies reviewed

\begin{tabular}{|c|c|c|c|}
\hline Author and year & Research tool & Sample & Results summary \\
\hline $\begin{array}{l}\text { Alharbi, Alotebi, } \\
\text { Masmali and } \\
\text { Alreshidi, } 2017\end{array}$ & $\begin{array}{l}\text { Questionnaire } \\
\text { based on UTAUT } \\
\text { Model }\end{array}$ & $\begin{array}{l}\text { Faculty members } \\
(80)\end{array}$ & $\begin{array}{l}\text { Effort expectancy is the best predictor of teachers' } \\
\text { behavioural intentions to use M-Learning. }\end{array}$ \\
\hline $\begin{array}{l}\text { Rutter and } \\
\text { Smith, } 2019\end{array}$ & $\begin{array}{l}\text { Questionnaire } \\
\text { based on UTAUT } \\
\text { Model }\end{array}$ & 171 students & $\begin{array}{l}\text { Performance expectancy, technical support and } \\
\text { social influence were direct contributors to an } \\
\text { individuals' behavioural intention to integrate the } \\
\text { LMS. Other parameters, for instance effort } \\
\text { expectancy and facilitating conditions, were not } \\
\text { found to be substantial predictors. }\end{array}$ \\
\hline $\begin{array}{l}\text { Alasmari and } \\
\text { Zhang, } 2019\end{array}$ & \begin{tabular}{lr}
\multicolumn{2}{l}{ Questionnaire } \\
based on & UTAUT \\
Model & and \\
interviews &
\end{tabular} & $\begin{array}{l}\text { Male (591) and } \\
\text { female (612) } \\
\text { students, with } 15 \\
\text { interviews }\end{array}$ & $\begin{array}{l}\text { Characteristics of mobile learning, effort expectancy, } \\
\text { learning expectancy and social influence were } \\
\text { significant predictors of learners' intentions to use } \\
\text { M-Learning technologies. }\end{array}$ \\
\hline Zalah, 2018 & \begin{tabular}{lr}
\multicolumn{2}{l}{ Questionnaire } \\
based on & UTAUT \\
Model & and \\
interviews &
\end{tabular} & Instructors (347) & $\begin{array}{l}\text { Attitudes, effort expectancy, education policy and } \\
\text { performance had positive effects on tutors' intention } \\
\text { to integrate E-Learning techniques. }\end{array}$ \\
\hline Alasmari, 2017 & \begin{tabular}{l}
\multicolumn{2}{l}{ Questionnaire } \\
based on UTAUT \\
Model \\
interviews
\end{tabular} & $\begin{array}{lr}\text { Students } & (1203) \\
\text { and } & 15 \\
\text { interviewees } & \end{array}$ & $\begin{array}{l}\text { E-Learning experience, age and gender had a } \\
\text { moderating effect on the intention to use M- } \\
\text { Learning. }\end{array}$ \\
\hline $\begin{array}{l}\text { AlMarwani, } \\
2016\end{array}$ & $\begin{array}{l}\text { Questionnaire } \\
\text { based on UTAUT } \\
\text { Model }\end{array}$ & $\begin{array}{l}878 \text { students and } \\
65 \text { teachers }\end{array}$ & $\begin{array}{l}\text { The social influence variable, hedonic, facilitating } \\
\text { conditions, performance expectancy, habit and } \\
\text { motivation accounted for } 49.3 \% \text { of the variance in } \\
\text { the behavioural intention to adopt M-Learning } \\
\text { technologies in learning English as a foreign } \\
\text { language. }\end{array}$ \\
\hline Khan 2017 & $\begin{array}{l}\text { Questionnaire } \\
\text { based on UTAUT } \\
\text { Model }\end{array}$ & $\begin{array}{ll}316 & \text { faculty } \\
\text { members } & \end{array}$ & $\begin{array}{l}\text { Social influence and effort expectancy had a positive } \\
\text { impact on behavioural intention. }\end{array}$ \\
\hline
\end{tabular}

\section{CONCLUSION AND FUTURE WORK}

This paper reviewed recently published literature that used the UTAUT Model as a guideline for research in Saudi education. It aimed to provide a comprehensive understanding of the current research that is available for researchers which used this kind of framework. In other words, the results from this study identified the gap in the literature specifically related to this model. Based on the evaluation and examination of the aforementioned papers and research findings, it could be stated that factors such as social influence, facilitating conditions, performance expectancy and effort expectancy had positive effects on users' intention to utilise technologies in the Saudi education environment.

This paper recommends areas for future work. Firstly, this paper is limited to reviewing literature about the adoption of the UTAUT Model in Saudi Arabia. As a result; future work could focus on systematic literature reviews of the use of the TAM framework in studies conducted in the Saudi education setting. Also, more research is needed to examine the students' and educators' 
perceptions of the use of new technologies such as Google Classroom in the education environment. This could be done through a questionnaire based on the UTAUT framework.

\section{References}

Alasmari, T. and Zhang, K., 2019. Mobile learning technology acceptance in Saudi Arabian higher education: an extended framework and a mixed-method study. Education and Information Technologies, 24(3), pp.2127-2144.

Alasmari, T.M., 2017. Mobile learning technology acceptance among Saudi higher education students (dissertation).

AlMarwani, M.A., 2016. E3-Electronic education for English: developing mobile learning and teaching in Saudi Arabia (Doctoral dissertation, University of Lincoln).

Alshehri, A., Rutter, M.J. and Smith, S., 2019. An implementation of the UTAUT model for understanding students' perceptions of learning management systems: A study within tertiary institutions in Saudi Arabia. International Journal of Distance Education Technologies (IJDET), 17(3), pp.1-24.

Khan, R.A., 2017. Adoption of learning management systems in Saudi higher educational institutions (Doctoral dissertation, University of Portsmouth).

Williams, M.D., Rana, N.P. and Dwivedi, Y.K., 2015. The unified theory of acceptance and use of technology (UTAUT): a literature review. Journal of Enterprise Information Management

Zalah, I., 2018. Factors that influence Saudi secondary teachers' acceptance and use of E-learning technologies (Doctoral dissertation, University of Brighton). 